\title{
ACTA AGROBOTANICA \\ Vol. 64 (3): 35-38 \\ 2011 \\ INFLUENCE OF ROW SPACING ON HERB YIELD OF COMMON CHAMOMILE (Chamomilla recutita (L.) Rausch.) AS WELL AS SEED YIELD AND QUALITY
}

\author{
Agnieszka Surmacz-Magdziak \\ Institute of Plant Genetics, Breeding and Biotechnology, University of Life Sciences, Akademicka 15, 20-950 Lublin, Poland, \\ e-mail: asm@up.lublin.pl
}

Received: 28.01.2011

\begin{abstract}
The experiment consisted of three single row spacings (every 25, 40 and $50 \mathrm{~cm}$ ) and four double and triple row spacings (40-25-40 cm, 40-25-25-40 cm, 50-25-50 cm, 50-25-25$50 \mathrm{~cm}$ ). The aim of the present experiment was to compare the influence of varying spacing on yields and quality of chamomile seeds. Among the row spacings under comparison, the highest seed and herb yields were achieved from the triple row spacing. 1000 -seed weight was proportional to seed yield, and the seed germination capacity was not differentiated due to row spacings used. Plants growing in single rows every $25 \mathrm{~cm}$ formed the lowest number of branches terminated by flower heads, thus the herb and seed yields were the lowest.
\end{abstract}

Key words: chamomile, row spacing, triple spacing, double spacing, seeds, herbs, 1000-seed weight, germination capacity

\section{INTRODUCTION}

Common chamomile (Chamomilla recutita (L.) Rausch.), family Asteraceae, is a native of southern and eastern Europe. Today, however, this species has spread throughout most of the European continent and can be observed in North Africa, Asia, North and South America as well as Australia (P o u r o h it and V y a s, 2004). The plant has considerable ecological amplitude and can adapt to less than optimum climatic and soil conditions ( $\mathrm{N}$ i r r , 2002). Chamomile is the oldest and the most common medicinal plant. It was highly prized by the ancient Greeks and is still popular today. Flower heads collected at full bloom stage are herbal materials. In phytotherapy, mainly flower anthodia (Flos chamomilae) are used. The chamomile drug is included in the pharamacopoeia of 26 countries. Chamomile underlies commercially produced medicinal preparations and a variety of cosmetic preparations (Kordan a et al. 1996; Kołodziej, 2010). This chamomile drug has anti-inflammatory, antiseptic, stimulative, carminative, spasmolytic and sedative activity. The medicinal attributes of the chamomile drug are due to the specific constituents of essential oil, including (-) bisabolol, chamazulene and farnesene (Franke and S chilcher, 2007; S a ze g a r et al. 2010; S rivas t a va et al. 2010). Extracts of the plant are added to a variety of cosmetic preparations such as creams, soaps, skin lotions, bath preparations, and hair conditioners (B ot c her et al. 2001). The chamomile herb (Herba chamomillae) also contains essential oils and, after processing, flowers remain which are also used as high-quality feed for animals (G o r e c k i , 2001).

Due to its both medicinal and industrial importance, chamomile is mass-produced in many countries, including Poland (Kordana et al. 1996; Kołod z i e j, 2010).

The high demand for raw material and seeding material due to the medicinal value of chamomile made the author to undertake a study on modifications of up-to-date agricultural practices in growing this plant species which can have positive effects on yields.

Among agrotechnical factors, an appropriate spacing ensuring optimum conditions for plant growth and development is an important yield-forming element ( $\mathrm{Z}$ a ł ę c k i , 1972; J a m s hi d i, 2000).

The aim of the present experiment was to compare the influence of varying spacing on yields and quality of chamomile seeds.

\section{MATERIALS AND METHODS}

The field experiment was carried out in 20012003 in Ostrów Lubelski on sand-loamy soil developed 
from strong loamy sands. This type of soil is characterized by high contents of available phosphorus and potassium forms, neutral acidity; moreover, it is well-aerated, permeable, and can be quickly warmed up (Table 1). White mustard cultivated for green forage was chamomile's (Chamomilla recutita) forecrop. Uniform mineral fertilization was applied every year $\left(\mathrm{kg} \times \mathrm{ha}^{-1}\right): \mathrm{N}-50, \mathrm{P}-26$ and $\mathrm{K}-67$. The experiment was set up as a complete randomized design in four replications, taking into account the following spacings: single rows every $40 \mathrm{~cm}$ (control), single rows every $50 \mathrm{~cm}$, single rows every $25 \mathrm{~cm}$, double rows every $25 \mathrm{~cm}$ by turns with $40 \mathrm{~cm}$ spacing (40-25-40), triple rows every $25 \mathrm{~cm}$ by turns with $40 \mathrm{~cm}$ spacing (40-25-25-40), double rows every $25 \mathrm{~cm}$ by turns with $50 \mathrm{~cm}$ spacing (50-25-50), and triple rows every $25 \mathrm{~cm}$ by turns with $50 \mathrm{~cm}$ spacing (50-25-25-50). Seeds of

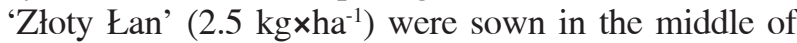
April in $27.5 \mathrm{~m}^{2}$ area plots. The final plant height and number of branches terminated by flower heads were determined using 10 randomly selected chamomile plants from each plot prior to harvest of herbs with inflorescences grown for seeds. The herb harvest was done when the plantation turned yellow, which resulted from tubular flowers and flower heads that had become crumbled, thus about 15 days after the start of flowering.

Herbs together with inflorescences were cut using a cutter just at the stem base, and then their fresh matter was weighed. After drying at $35^{\circ} \mathrm{C}$, the air-dry herb weight was determined. The herb was threshed and seeds were separated from other fractions using sieves of $3,1,0.8$, and $0.4 \mathrm{~mm}$ mesh, and then their yields were assessed. The qualitative evaluation of seeds consisted in determining 1000-seed weight and germination capacity.

The results were statistically processed using Tukey's test at the 5\% error level.

\section{RESULTS AND DISCUSSION}

There are few agrotechnological literature references on common chamomile cultivation applying twin row spacing. Instead, $40 \mathrm{~cm}$ spaces between plant rows are recommended ( $\mathrm{Z}$ a łę c ki, 1972; K ord a$\mathrm{n}$ a et al. 1996; J a m shidi, 2000).

Spacing applied in the present experiment significantly influenced chamomile traits. Plants growing in single rows every $25 \mathrm{~cm}$ were the highest, while those growing in the single row spacing every $50 \mathrm{~cm}$ the shortest. Plants growing in the triple row spacing were characterized by the highest number of branches terminated by flower heads. Their lowest number was produced by plants in single row spacing every $25 \mathrm{~cm}$ (Table 2). The obtained results are consistent with those of Gruszczyk (2001) who found that St. John's wort cultivation in twin row spacing positively affected the number of branches. Twin row spacing had a significant influence on chamomile yield. Among the compared spacing types, the highest fresh and dry herb yield was obtained from triple row spacing, the lowest one - from single row spacing every $25 \mathrm{~cm}$ (Table 2). Such results were confirmed by other authors (Ko o odziej and Zejdan, 2000; Gruszczyk, 2001; S ugier, 2004) who found that St. John's wort, fenugreek and dandelion cultivation in double row spacing gave higher raw material yields than in single row spacing. The fresh to dry weight ratio for the herb - from diverse spacings reached similar values: 4.5-4.6. The spacing applied in the experiment significantly modified seed yields. Chamomile plants grown in twin row spacing were higher and had more branches terminated by flower heads, which affected the increase in herb and seed yield.

The highest seed yields were achieved in triple row spacing (higher by $24 \%$ as compared to the control spacing), while the lowest ones in single row spacing every $25 \mathrm{~cm}$ (lower by $8 \%$ in comparison to the control). When comparing the yields from the treatments where single rows every 40 and $50 \mathrm{~cm}$ were used, no significant differences were found; however, the increasing tendency in single row spacing of $50 \mathrm{~cm}$ was prominent (Table 3 ). Gajzle row ic z (1971) reported that $0.26{\mathrm{t} \times \mathrm{ha}^{-1}}^{-}$seed yield could be achieved under Polish conditions, whereas $\mathrm{C} \mathrm{z}$ a b a j $\mathrm{s} \mathrm{k}$ a et al. (1978) indicated that it could oscillate from

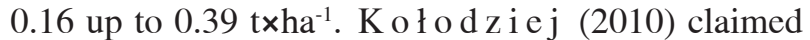
that seed yields of chamomile grown at $40 \mathrm{~cm}$ row

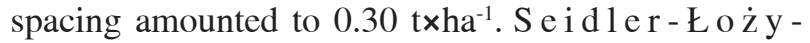
k ow sk a (2000) found that it could be even higher up to $0.41 \mathrm{tx} \mathrm{ha}^{-1}$. In my own experiment, seed yields from this spacing changed within the above range,

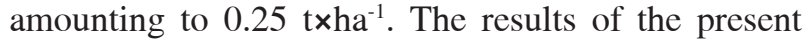
study were confirmed by the experiments of $\mathrm{Gru} \mathrm{s} \mathrm{z-}$ c z y k (2000) who proved that twin row spacing caused an increase in St. John's wort seed yields by $17 \%$ on average in relation to single spacing.

Diverse row spacing applied in the present experiment had no crucial impact on seed germination capacity. The values of this trait were similar and amounted to $86-90 \%$, which was confirmed by $\mathrm{Gru} \mathrm{s} \mathrm{Z-}$ c z y k (2000) who reported that St. John's wort cultivation in twin row spacing had no effects on seed germination capacity, either.

1000 -seed weight for chamomile at spacings applied in the experiment oscillated within the range of $0.100-0.107 \mathrm{~g}$, although the highest value of this trait was recorded from triple row spacing $50-25-25-50 \mathrm{~cm}$, while the lowest one in single row spacing every $25 \mathrm{~cm}$ (Table 3). 
Table 1

Contents of macroelements and microelements in the soil

\begin{tabular}{cccccccccc}
\hline \multirow{2}{*}{$\begin{array}{c}\text { pH in } 1 \mathrm{~m} \\
\mathrm{KCl}\end{array}$} & \multicolumn{3}{c}{ Macroelements $\mathrm{mg} \times \mathrm{kg}^{-1}$ soil } & \multicolumn{4}{c}{ Microelements } \\
\cline { 2 - 10 } & $\mathrm{P}$ & $\mathrm{K}$ & $\mathrm{Mg} \times \mathrm{kg}^{-1}$ soil \\
\hline 6.7 & 141.0 & 154.0 & 51.0 & 0.36 & 2.7 & 276.0 & 11.8 & 915.0 \\
\hline
\end{tabular}

Table 2

Influence of row spacing on some plant traits and herb yield of common chamomile (mean values for 2001-2003).

\begin{tabular}{|c|c|c|c|c|c|}
\hline $\begin{array}{l}\text { Row spacing } \\
(\mathrm{cm})\end{array}$ & $\begin{array}{l}\text { Plant height } \\
(\mathrm{cm})\end{array}$ & $\begin{array}{l}\text { Number of branches terminated } \\
\text { by flower heads (per plant) }\end{array}$ & $\begin{array}{l}\text { Fresh herb yield } \\
\qquad\left(\mathrm{t} \times \mathrm{ha}^{-1}\right)\end{array}$ & $\begin{array}{l}\text { Air-dry herb yield } \\
\qquad\left(\mathrm{t} \times \mathrm{ha}^{-1}\right)\end{array}$ & $\begin{array}{l}\text { Fresh to dry } \\
\text { weight ratio }\end{array}$ \\
\hline 40 & 58.7 & 10.1 & 14.5 & 3.2 & 4.5 \\
\hline 50 & 57.8 & 10.5 & 14.7 & 3.3 & 4.5 \\
\hline 25 & 65.2 & 8.6 & 12.0 & 2.6 & 4.6 \\
\hline $40-25-40$ & 60.7 & 11.8 & 17.0 & 3.8 & 4.5 \\
\hline $40-25-25-40$ & 63.7 & 13.5 & 17.6 & 3.8 & 4.6 \\
\hline $50-25-50$ & 60.6 & 12.4 & 16.7 & 3.6 & 4.6 \\
\hline $50-25-25-50$ & 62.8 & 14.1 & 18.2 & 4.0 & 4.6 \\
\hline Mean & 61.4 & 11.6 & 15.8 & 3.5 & 4.6 \\
\hline $\mathrm{LSD}_{0.05}$ & 2.01 & 1.23 & 1.25 & 0.27 & - \\
\hline
\end{tabular}

Table 3

Yield of seeds and their qualitative evaluation (mean values for 2001-2003)

\begin{tabular}{|c|c|c|c|}
\hline Row spacing $(\mathrm{cm})$ & Seed yields $\left(\mathrm{t} \times \mathrm{ha}^{-1}\right)$ & 1000 -seed weight $(\mathrm{g})$ & Germination capacity (\%) \\
\hline 40 & 0.25 & 0.103 & 88 \\
\hline 50 & 0.26 & 0.103 & 88 \\
\hline 25 & 0.23 & 0.100 & 86 \\
\hline $40-25-40$ & 0.29 & 0.104 & 90 \\
\hline $40-25-25-40$ & 0.31 & 0.106 & 90 \\
\hline $50-25-50$ & 0.30 & 0.106 & 89 \\
\hline $50-25-25-50$ & 0.31 & 0.107 & 90 \\
\hline Mean & 0.28 & 0.104 & 90 \\
\hline $\mathrm{LSD}_{0.05}$ & 0.02 & 0.005 & r.n. \\
\hline
\end{tabular}

\section{CONCLUSIONS}

Among the types of row spacing compared, the most beneficial was triple row spacing (40-25-25 $-40 \mathrm{~cm}, 50-25-25-50 \mathrm{~cm}$ ). Herb and seed yields obtained from that spacing were the highest. 1000-seed weight was proportional to seed yield, and the seed germination capacity was not differentiated due to row spacings used.

Single row spacing every $25 \mathrm{~cm}$ appeared to be the least beneficial. Plants produced from it formed the lowest number of branches terminated by flower heads, thus herb and seed yields were the lowest.

It is recommended to cultivate chamomile at triple row spacing.

\section{REFERENCES}

Botcher H., Gunter I., Frank R., Warnstorff K., 2001. Physiological postharvest response of Matricaria (M. recutita) flowers. Postharvest Biol. Technol. 22 (1) : 39-51. 
Czabajska W., Dąbrowska J., Kaźmierczak K., Maciołowska - Ludowicz E., 1978. Nasiennictwo rumianku pospolitego (Matricaria chamomilla L.) odmiany Złoty Łan. / Seed data for chamomile (Matricaria chamomilla L.) cv. 'Złoty Łan'. Herba Pol. 1/2: 57-63 (in Polish).

Franke R., Schilcher H., 2007. Relevance and use of chamomile (Matricaria recutita L.). Acta Hort. 749:29-43.

Gajzlerowicz M., 1971. Plantacja nasienna rumianku pospolitego. / Seeding plantation of chamomile. Ziel. Biul. Inf. 6: 4-5 (in Polish).

Gorecki P., 2001. Surowce roślinne w lecznictwie i profilaktyce, w żywieniu i kosmetyce. / Plant raw materials in medicine and prevention, in nutrition and cosmetics. Herba Pol. XLVII (2): 85-103 (in Polish).

Gruszczyk M., 2000. Wpływ rozstawy rzędów na plony i jakość nasion dziurawca zwyczajnego (Hypericum perforatum L.). / Effect of row spacing on yield and quality of St. Johns Wort (Hypericum perforatum L.) seeds. Rocz. AR Pozn. CCCXXIII, Ogrodn. 31 (1): 283-287 (in Polish).

Grus zc z y k M., 2001. Wpływ rozstawy rzędów oraz warunków glebowych na wzrost i plony ziela dziurawca zwyczajnego (Hypericum perforatum L.). / Effect of row spacing and soil conditions on the growth and yield of St. Johns Wort (Hypericum perforatum L.). Herba Pol. 2 : 125-129 (in Polish).

Jamshidi K., 2000. Effects of row spacing and plant density on quantitative aspects of chamomile flower $(\mathrm{Ma}$ tricaria chamomilla L.). Iranian J. Agric. Sci. 31 (1): 203-210.

Kołodziej B., 2010. Uprawa ziół: poradnik dla plantatorów. Państwowe Wydawnictwo Rolnicze i Leśne, Poznań.

Kołodziej B., Zejdan E.M., 2000. Wpływ sposobu rozmieszczenia rzędów na plonowanie kozieradki polskiej i egipskiej. / The effect of row spacing on Polish and Egyptian fenugreek yielding. Rocz. AR Pozn. CCCXXIII 31 (1): 325-329 (in Polish).

Kordana S, Kucharski W, Mikołajewicz M, Załęcki R., 1996. Rumianek pospolity (Chamomilla recutita (L.) Rauschert). / Common chamomile (Chamomilla recutita (L.) Rauschert). Wiad. Ziel. 2-7.

N i r r B ., 2002. Herb cultivation and their utilization. Asia Pacific Busines Inc., Delhi, India.

Pourohit S.S., Vyas S.P., 2004. Medicinal plant cultivation. Agrobios, India.

Sazegar M.R., Banakar A., Bahrami N., Bahrami A., Baghbani M., Nematolahi P.,
Mott a g h i M., 2010. The antioxidant activity of chamomile (Matricaria chamomilla L.) extract in sunflower oil. World Applied Sci. J. 9: (8), 873-878.

Seidler-Łożykowska K., 2000. Doświadczenie porównawcze rodów i odmian rumianku pospolitego o podwyższonej zawartości $\alpha$-bisabololu. Cz. II. / Comparison of some traits of chamomile strains and varieties with an increased content of $\alpha$-bisabolol. Part II. Herba Pol. 1: 5-11 (in Polish).

Srivastava J.K., Shankar E., Gupta S., 2010. Chamomile: A herbal medicine of the past with a bright future (review). Mol. Med. Report. 3, 6: 895-901.

Sugier D., 2004. Wpływ rozstawy rzędów oraz sposobu zakładania plantacji na plonowanie mniszka lekarskiego (Taraxacum officinale Web.). I The effect of row spacing and plantation establishment on common dandelion yielding (Taraxacum officinale Web.). Ann. UMCS Sect. E, 59 (2): 535-541 (in Polish).

Załęcki R., 1972. Uprawa i nawożenie tetraploidalnego rumianku pospolitego (Matricaria chamomilla L.). I Cultivation and fertilization of the tetraploidal form of Matricaria chamomilla L.). Herba Pol. 18 (1) : 70-78 (in Polish).

\section{Wpływ rozstawy rzędów na plon ziela rumianku pospolitego [Chamomilla recutita (L.) Rausch.] oraz plon i jakość nasion}

\section{Streszczenie}

W doświadczeniu polowym zastosowano trzy rozstawy rzędów rozmieszczonych pojedynczo (co $25,40,50 \mathrm{~cm}$ ) oraz cztery rozstawy w pasowym układzie rzędów podwójnych i potrójnych (40-25-40 cm, 40-25-25-40 cm, 50-25-50 cm, 50-25-25-50 cm). Celem przeprowadzonego doświadczenia było porównanie wpływu zróżnicowanej rozstawy rzędów na plonowanie oraz jakość nasion rumianku pospolitego. Spośród zastosowanych rozstaw rzędów najwyższy plon nasion oraz ziela otrzymano z rozstaw pasowych potrójnych. Masa tysiąca nasion była proporcjonalna do plonu nasion, zaś zdolność kiełkowania nie różniła się w zależności od zastosowanych rozstaw rzędów. Rośliny rosnące $w$ rozstawie co $25 \mathrm{~cm}$ tworzyły najmniej rozgałęzień zakończonych koszyczkami, a w związku z tym uzyskany z tej rozstawy plon ziela i nasion był najniższy. 